\title{
Development of Gastroretentive Floating Tablets Quetiapine Fumarate
}

\author{
Priyanka Lekhwar¹, Dr. P. K. Sahoo², Ravindra Agarwal ${ }^{3}$, Amit Sharma4 \\ 1Department of Pharmaceutics, Master in Pharmaceutics, Delhi, India \\ 2Department of Pharmaceutics, Delhi Institute of Pharmaceutical Sciences \& Research, Delhi, India \\ 3Senior Manager, Production Department Sun Pharma, Scientist, Delhi, India \\ ${ }^{4}$ Scientist, Production Department Sun Pharma, Scientist, Delhi, India
}

\begin{abstract}
How to cite this paper: Priyanka Lekhwar | Dr. P. K. Sahoo | Ravindra Agarwal | Amit Sharma "Development of Gastroretentive Floating Tablets Quetiapine Fumarate" Published in International Journal of Trend in Scientific Research and Development (ijtsrd), ISSN: 2456-6470, Volume-3 | Issue-4, June 2019, pp.1037-1040, URL: https://www.ijtsrd.c om/papers/ijtsrd24 051.pdf

Copyright (C) 2019 by author(s) and

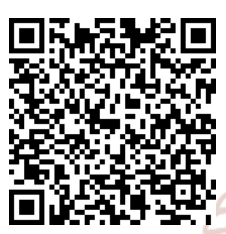
IITSRD24051 International Journal of Trend in Scientific Research and Development Journal. This is an Open Access article distributed under the terms of the Creative Commons Attribution License (CC BY 4.0)

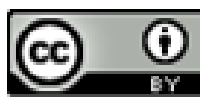

(http://creativecommons.org/licenses/ by $/ 4.0$ )
\end{abstract}

\section{ABSTRACT}

The idea of the study is to prepare and characterize a sustain release floating tablets of Quetiapine Fumarate for Schizophrenia. Materials which are used in making of effervescent Tablets are hydroxy-methylcellulose HPMC. For the buoyancy sodium bicarbonate is used. Initially for the selection of formulation Definitive screening design is used which allows to study the effect of large number of factors in relatively small experiment. The optimized formulation is tested for release rate, buoyancy, hardness, thickness, floating time, swelling study and release rate. These studies shows that optimized tablet remains in stomach for $24 \mathrm{~h}$ and shows release rate of $91 \%$ which is very desirable.

Keywords: Quetiapine Fumarate, Effervescent Tablet, HPMC, Definitive Study Design

\section{INTRODUCTION}

An approach for prolonging gastric residence time, with targeting the upper part of Gastrointestinal is known as the gastro-retentive drug delivery. They are needed for sustained drug delivery systems. Since they release drug in very optimal way by release it before the absorption window. The increased gastric retention time further increases bioavailability, decreases drug wastage, and enhances solubility property of drug which are minimal soluble in increased $\mathrm{pH}$ environment. Quetiapine Fumarate is widely antipsychotic used for schizophrenia disorder. It is used in the initial stages of the disease. Its sustained release tablet dose regimen is $300 \mathrm{mg}$ once daily. Solubility of quetiapine fumarate is $\mathrm{pH}$ dependent it is highly soluble in the acidic environment while less in basic.
When the formulation goes into the solution the layer of gel is retained with the alongside hydrocolloid layer turns hydrated. The trapped air in the bloated polymer keeps density below unity and provides buoyancy to the formulation. ${ }^{[1]}$

The floating formulation has many merits since they are less susceptible to gastric emptying Which minimises the divergence in plasma drug levels, very proficient for narrow absorption windows drugs, minimise dosing and elevate patient compliance, slashes the $\mathrm{C}$ max and extend level of drug above minimum effective concentration. Quetiapine Fumarate has site specific absorption which gives good rationale for its use as a gastroretentive dosage form. ${ }^{[2]}$

\section{Characteristics of Gastro-Retentive Tablets}

1. Acts in stomach e.g antacids ${ }^{[3]}$

2. Absorb in stomach e.g amoxicillin ${ }^{[4]}$

3. Interrupt colonic microbes e.g antibiotics for H.pylori ${ }^{[5]}$

4. Degraded in colon e.g metformin[6]

5. Absorbed instantly from GIT e.g Metronidazole ${ }^{[7]}$
Experimental Materials

\begin{tabular}{|c|c|c|}
\hline S. N & Experimental Materials & Details \\
\hline 1. & Quetiapine Fumarate & $\begin{array}{c}\text { Sunpharma } \\
\text { Laboratories }\end{array}$ \\
\hline 2. & HPMC K100M & $\begin{array}{c}\text { Sunpharma } \\
\text { Laboratories }\end{array}$ \\
\hline 4. & Sodium Bicarbonate & $\begin{array}{c}\text { Sunpharma } \\
\text { Laboratories }\end{array}$ \\
\hline 5. & Sodiumpharma Alginate & $\begin{array}{c}\text { Suboratories } \\
\text { Laboratories }\end{array}$ \\
\hline 6. & Talc & $\begin{array}{c}\text { Sunpharma } \\
\text { Laboratories }\end{array}$ \\
\hline 7. & Colloidal Silica & $\begin{array}{c}\text { Sunpharma } \\
\text { Laboratories }\end{array}$ \\
\hline 8. & Magnesium Stearate & $\begin{array}{c}\text { Sunpharma } \\
\text { Laboratories }\end{array}$ \\
\hline 9. & MCC 101 Grade & $\begin{array}{c}\text { Sunpharma } \\
\text { Laboratories }\end{array}$ \\
\hline 10. & Lactose & $\begin{array}{c}\text { Sunpharma } \\
\text { Laboratories }\end{array}$ \\
\hline
\end{tabular}

Formulation Preparation 
Direct compression method was used for the preparation of Quetiapine Fumarate. All the excipients are passed through ASTM50. Then all excipients are weighed individually and mixed to get consistent polymer mixture.[8] Then API was mixed with the polymer mixture for getting an uniform blend of the drug. ${ }^{[9]}$ Then powder mixtures with the help of magnesium sterate gets lubricated and compressed for obtaining tablets.[10] Formulation and Composition of Quetiapine fumarate effervescent tablet shown in Fig. 1

Composition of Floating Tablets (MG) Fig. 1

\begin{tabular}{|c|c|c|c|c|c|c|c|c|c|c|}
\hline Sr. No. & $\begin{array}{c}\text { Qutiapine } \\
\text { Fumarate }\end{array}$ & $\begin{array}{c}\text { Sodium } \\
\text { Bicarbonate }\end{array}$ & $\begin{array}{c}\text { Sodium } \\
\text { Alginate }\end{array}$ & $\begin{array}{c}\text { HPMC } \\
\text { K100M }\end{array}$ & Talc & Silica & LVCR & Lactose & $\begin{array}{c}\text { Mg } \\
\text { Stearate }\end{array}$ & MCC \\
\hline F1 & 230.27 & 40 & 30 & 166 & 4.5 & 4.5 & 0 & 20.23 & 4.5 & 50 \\
\hline F2 & 230.27 & 20 & 0 & 90 & 4.5 & 4.5 & 0 & 146.23 & 4.5 & 50 \\
\hline F3 & 230.27 & 10 & 0 & 90 & 4.5 & 4.5 & 30 & 136.23 & 4.5 & 50 \\
\hline F4 & 230.27 & 10 & 30 & 128 & 4.5 & 4.5 & 30 & 68.23 & 4.5 & 50 \\
\hline F5 & 230.27 & 20 & 30 & 166 & 4.5 & 4.5 & 30 & 10.23 & 4.5 & 50 \\
\hline F6 & 230.27 & 40 & 0 & 128 & 4.5 & 4.5 & 0 & 88.23 & 4.5 & 50 \\
\hline F7 & 230.27 & 20 & 15 & 128 & 4.5 & 4.5 & 15 & 78.23 & 4.5 & 50 \\
\hline F8 & 230.27 & 20 & 15 & 128 & 4.5 & 4.5 & 15 & 78.23 & 4.5 & 50 \\
\hline F9 & 230.27 & 40 & 15 & 166 & 4.5 & 4.5 & 0 & 75.23 & 4.5 & 50 \\
\hline F10 & 230.27 & 40 & 30 & 90 & 4.5 & 4.5 & 15 & 81.23 & 4.5 & 50 \\
\hline F11 & 230.27 & 10 & 0 & 166 & 4.5 & 4.5 & 15 & 75.23 & 4.5 & 50 \\
\hline F12 & 230.27 & 40 & 15 & 90 & 4.5 & 4.5 & 30 & 81.23 & 4.5 & 50 \\
\hline F13 & 230.27 & 10 & 30 & 90 & 4.5 & 4.5 & 0 & 136.23 & 4.5 & 50 \\
\hline F14 & 230.27 & 40 & 0 & 166 & 4.5 & 4.5 & 30 & 20.23 & 4.5 & 50 \\
\hline
\end{tabular}

\section{In Vitro Studies-}

\section{Total Floating Time}

The in vitro buoyancy was determined by the floating lag time. The time taken by the tablet to rise to the floating surface was determined by the buoyancy lag time and the timings of all the formulated tablets are determined by placing them in $100 \mathrm{ml}$ beaker contains $0.1 \mathrm{~N} \mathrm{HCl} \mathrm{(Fig.} \mathrm{2)}$

\begin{tabular}{|c|c|c|c|c|c|c|c|c|c|c|c|c|c|c|c|}
\hline TIMIE & T1 & T2 & T3 & T4 & T5 & T6 & T7 & T8 & T9 & T10 & T11 & T12 & T13 & T14 & T14 \\
\hline 1 & 37 & 53 & 14 & 12 & 17 & 31 & 15 & 17 & 14 & 50 & 18 & 36 & 16 & 12 & 12 \\
\hline 2 & 44 & 60 & 22 & 20 & 25 & 37 & 25 & 28 & 26 & 60 & 26 & 54 & 25 & 20 & 20 \\
\hline 6 & 56 & 67 & 48 & 42 & 48 & 56 & 49 & 55 & 41 & 74 & 48 & 70 & 45 & 39 & 39 \\
\hline 8 & 69 & 70 & 58 & 53 & 55 & 63 & 58 & 64 & 50 & 77 & 55 & 74 & 53 & 47 & 47 \\
\hline 10 & 71 & 69 & 65 & 59 & 66 & 68 & 65 & 71 & 54 & 80 & 62 & 79 & 59 & 52 & 52 \\
\hline 12 & 73 & 69 & 69 & 63 & 68 & 64 & 68 & 75 & 59 & 83 & 67 & 82 & 63 & 58 & 58 \\
\hline 16 & 75 & 76 & 74 & 67 & 78 & 78 & 77 & 82 & 84 & 84 & 73 & 85 & 69 & 67 & 67 \\
\hline 20 & 77 & 77 & 74 & 68 & 79 & 77 & 78 & 82 & 86 & 90 & 83 & 86 & 70 & 71 & 69 \\
\hline 24 & 78 & 78 & 77 & 68 & 79 & 77 & 79 & 83 & 88 & 92 & 85 & 84 & 77 & 72 & 71 \\
\hline
\end{tabular}

Fig. 2

\section{IN VITRO DISSOLUTION STUDIES}

Quetiapine Fumarate effervescent tablet release rate was determined by using USP II apparatus (Paddle type). This test ia performed by using $900 \mathrm{ml} 0.1 \mathrm{~N} \mathrm{HCl}$ at $37 \pm 0.5^{\circ} \mathrm{C}$ a sample was taken $7 \mathrm{ml}$ from the dissolution apparatus at systematic time intervals upto 24 hours $(1,2,4,6,8,10,12$, $16,20,24) \mathrm{hrs}$. and the sample is continuously changed with the same volume the fresh dissolution medium. Using membrane filter of $0.45 \mu$ samples are filtered out and they were analysed by UV/Visible spectrophotometer Shimadzu 1800 at $290 \mathrm{~nm}$.

\section{SWELLING AND EROSION STUDY}

After immersing in the medium the medium uptake and erosion was calculated. Sample are weighed and placed in dissolution baskets containing $0.1 \mathrm{~N} \mathrm{HCl}$ at $37 \pm 2^{\circ} \mathrm{C}$. After regular time interval the tablet from dissolution basket taken out, soaked up to eliminate excess water and reweighed on the analytical balance. The dampen samples are then dried for 24 hours at $70^{\circ} \mathrm{C}$ in oven then allowed to cool in the dessicators and weighed until the final constant dry weighed obtained. The medium uptake is the increase in the weight of wet mass it is calculated

according to the equation :

$\mathrm{Q}=100\left(\mathrm{~W}_{\mathrm{w}}-\mathrm{W}_{\mathrm{f}}\right) / \mathrm{W}_{\mathrm{f}}$

Absorbed liquid $=Q$

$\mathrm{W}_{\mathrm{w}}=$ hydrated sample before drying

$\mathrm{W}_{\mathrm{f}}=$ hydrated sample final mass

The percentage erosion (E) estimated using equation 2

$\mathrm{E}=100\left(\mathrm{~W}_{\mathrm{I}}-\mathrm{W}_{\mathrm{f}}-\mathrm{W}_{\mathrm{t}}\right) / \mathrm{W}_{\mathrm{I}}$

Where, $W_{I}=$ initial dry weight

$\mathrm{W}_{\mathrm{f}}=$ final mass and partially eroded sample

$\mathrm{W}_{\mathrm{t}}=$ theoretical weight of soluble component

Three different samples measured at varied time point. All experiments done in triplicate

\section{DEFINITIVE SCREENING DESIGN}

A definitve screening design (DSD) allows to study the effects of large number of factors in a relatively small experiment. DSD are an improvement on standard screening 
International Journal of Trend in Scientific Research and Development (IJTSRD) @ www.ijtsrd.com eISSN: 2456-6470

design (like plackett burman) that prevents confounding of factors and can also detect non-linear responses. DSDs can estimate quadratic (curvy linear) effects when the model contains only main effects and quadratic effects.

Trials were performed at 14 possible factors the amount of sodium alginate (X1), the amount of sodium bicarbonate, HPMC K100M, and Lactose they were selected as independent variables, the time required to $50 \%$ and $90 \%$ drug dissolution and in vitro floating lag time they were selected as dependent variables.

\section{RESULTS}

\section{DRUGS SOLUBILITY}

Quetiapine fumarate has $\mathrm{pH}$ dependent solubility highly soluble in acidic $\mathrm{pH}$ while very poor solubility in alkaline $\mathrm{pH}$. It has quantitative solubility of $33.2 \mathrm{mg} / \mathrm{ml}$ in $0.1 \mathrm{~N} \mathrm{HCl}$ as the $\mathrm{pH}$ rises solubility tremendously decreases i.e. $4.2 \mathrm{mg} / \mathrm{ml}$ in $\mathrm{pH} 4.5$ acetate buffer, $1.8 \mathrm{mg} / \mathrm{ml}$ in $\mathrm{pH} 6.8$ phosphate buffer.

\section{CHARACTERIZATION OF QUETIAPINE FUMARATE TABLET}

Variety of combinations are used of sodium alginate, sodium bicarbonate, HPMC K100M, HPMC K100 LVCR. They were used to make the matrix tabelts for sustained release of Quetiapine fumarate with effervescent property. There are all acceptable physical parametrs in all formulation due to their good flow and compressible property. Weight of all the tablets were in the range of $650 \pm 5 \mathrm{mg}$. Thickness of all the formulation is between 5.17 to 5.61 . Tablet hardness 12.8 to $15.5 \mathrm{kps}$. Weight loss in the friability test was $0.2-0.5 \%$ in all formulations. All the tablets are not disintegrating in the water.

\section{RATE KINETIC ANALYSIS}

Quetiapine Fumarate was analysed over the range 200$300 \mathrm{~nm}$ for $\lambda$ max determination. The observed peak was at $290 \mathrm{~nm}$ in UV spectrophotometer (Fig). Standard curve confirms the presence of Quetiapine fumarate in $0.1 \mathrm{~N} \mathrm{HCl}$

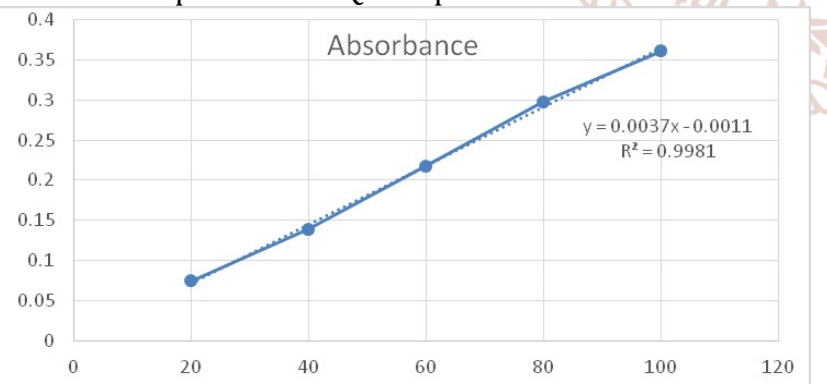

\begin{tabular}{|c|c|c|}
\hline S. No. & Conc. & Aborbance \\
\hline 1 & 20 & 0.075 \\
\hline 2 & 40 & 0.139 \\
\hline 3 & 60 & 0.218 \\
\hline 4 & 80 & 0.298 \\
\hline 5 & 100 & 0.361 \\
\hline
\end{tabular}

\section{IN VITRO BUOYANCY STUDY}

There were 14 formulations made and then characterized for their buoyancy lag time and total floating time. Sodium bicarbonate with $\mathrm{HCl}$ mainly responsible for the buoyancy in formulation. Buoyancy lag time range of all formulation found to be 20 seconds to 2 minutes. As the total floating time more than 12 hours for all formulation it shows stable gel formation by all polymers

\begin{tabular}{|c|c|c|}
\hline $\begin{array}{c}\text { FORMULA } \\
\text { CODE }\end{array}$ & $\begin{array}{c}\text { BUOYANCY } \\
\text { LAG TIME(sec) }\end{array}$ & $\begin{array}{c}\text { TOTAL FLOATING } \\
\text { TIME (hours) }\end{array}$ \\
\hline F1 & 93 & $>12$ \\
\hline F2 & 45 & $>12$ \\
\hline F3 & No floating & - \\
\hline F4 & No floating & - \\
\hline F5 & 40 & $>12$ \\
\hline F6 & 20 & $>12$ \\
\hline F7 & 112 & $>12$ \\
\hline F8 & No floating & - \\
\hline F9 & 43 & $>12$ \\
\hline F10 & 28 & $>12$ \\
\hline F11 & No floating & - \\
\hline F12 & 35 & $>12$ \\
\hline F13 & No floating & - \\
\hline F14 & No floating & - \\
\hline
\end{tabular}

\section{IN VITRO DISSOLUTION STUDIES}

The formulations T10 and T11 they were using HPMC K100 M, HPMC LVCR, Sodium Carbonate, and the $\%$ drug release was found to be 89 and $85 \%$ in 24 hours. Formulations T9 they were developed by using sodium bicarbonate, sodium alginate, lactose was found to be $91 \%$. Formulation T9 selected as optimised formulation based on the better drug release, lag time and total floating time.

cumulative \% drug release of formulation F1-F7
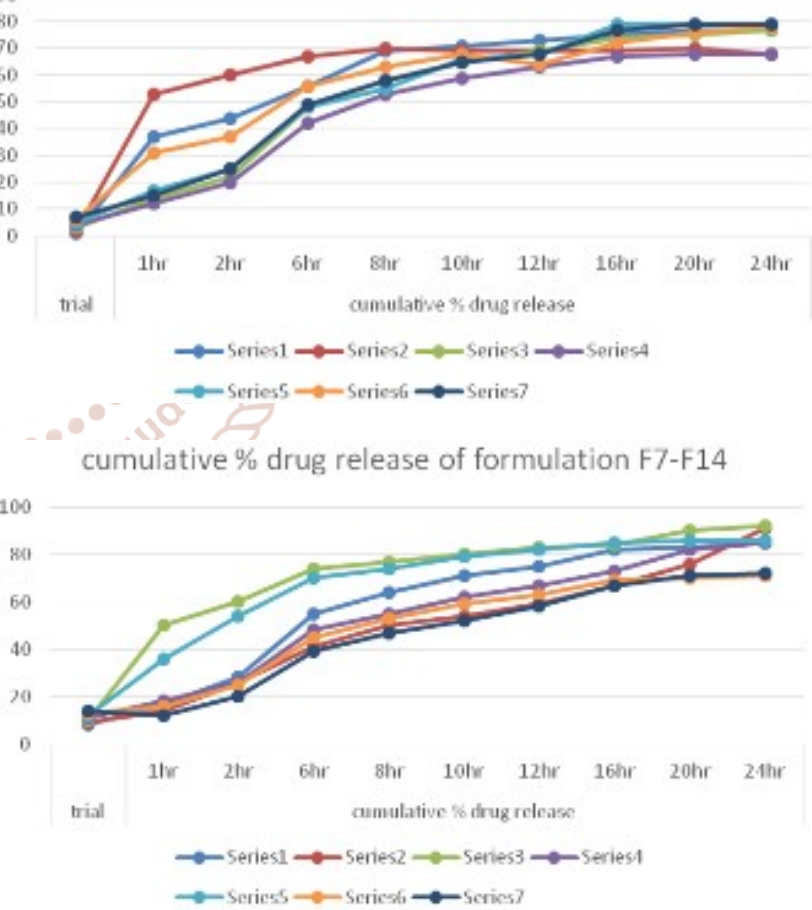

\section{OPTIMIZATION OF FORMULATION}

Trial 9 exhibit extended drug release profile with desirable floating lag time, consequently this trial was selected for definitive screening design studies to optimize the formulation and effects of variables on formulation. Effects of main variables are estimated in two stages and their combined effects.

The two stages are :

Stages 1 - Main effects estimates

Stages 2 - Even order effects estimates

Combined model parameters estimates ( HPMC K100 M, Sodium bicarbonate) 
Definitive screening of design for Dissolution

Conclusion of stages parameter: As the concentration of sodium bicarbonate increases, dissolution time also increases. However, no effect of sodium alginate in dissolution time. Further, as the concentration of HPMC K100 M increases dissolution time also decreases. Consequently, the gastric residence time increases.

\section{FLOATING TIME}

Floating time increases with increases in concentration of sodium bicarbonate. Sodium alginate ,HPMC K100 M and HPMC K100 LVCR has no effects in floating time.

\section{Summary and Conclusions:}

Present study illustrates the formulations of extended release effervescent based floating drug delivery system. Different polymers in different concentrations like sodium bicarbonate, sodium alginate, HPMC K100 M and HPMC K 100 LVCR were used to achieve the desired formulation of gastroretentive floating tablet. Definitive screening design unveil that the amount of sodium bicarbonate, HPMC K 100 $\mathrm{M}$, sodium alginate and HPMC k 100 LVCR had a remarkable effect on release rate of drug so therefore a suitable combination of polymer in appropriate concentrations were used to achieve desired dissolution profile. Based on Evaluations, Trail 9 was selected for optimization. Evaluation parameters like floating lag time, Buoyancy period and in vitro drug release were used and found better than other formulations. optimized formulation was compared with the marketed sustained Seroquel tablet. It was found that the release rate of gastro retentive Quetaipine fumarate has comparable release rate as marketed sustained Seroquel. Short floating time. Extended release of drug indicates higher residence time in the stomach and finally improves the Bioavailbility is the major issue in conventional quetiapine fumarate tablets.

\section{References:-}

[1] Rouge N, Buri P, Doelker E. Drug absorption sites in the gastrointestinal tract and dosage forms for site specific delivery. Int J Pharm. 1996; 136: 117- 139.
[2] Singh BN, Kim KH. Floating drug delivery systems: an approach to oral controlled drug delivery via gastric retention. J. Control Release. 2000; 63: 235-239.

[3] Harshal P, Gahiwade V, Manohar P, Bharat Tekade W, Vinod Thakare M, Patil V R. formulation and in-vitro evaluation of trifluoperazine hydrochloride bilayer floating tablet. Int J of Phar Bio Sic. 2012; 2

[4] Tadros M. Eur J of Pharma and Biopharma. Controlledrelease effervescent floating matrix tablets of ciprofloxacin hydrochloride: Development, optimization and in vitroin vivo evaluation in healthy human volunteers.2010; 74: 332-339.

[5] Desai S, Bolton S. A Floating Controlled Release Drug Delivery System: In vitro-In vivo Evaluation. Pharma. Res. 1993; 10 (9):1321-1325.

[6] In Vitro and In Vivo Evaluation of Quetiapine Fumarate controlled gastroretentive floating drug delivery system A. Kishore Babu1, 2, , M.V.Ramana1

[7] Siepmann J, Peppas N.A. Modeling of drug release from delivery systems based on hydroxypropyl methylcellulose (HPMC). Adv Drug Delivery Reviews. 2001; 48: 139-157.

[8] Sarojini S, Arivazagan D, Manavalan R and Jayanthi V: Buoyant Sustained Release Tablets Based On Polyethylene Oxide. International Journal of Pharmacy and Pharmaceutical Sciences 2010; 2(1): 144-49.

[9] Mantry S, Thilothama LR and Shashanka D: Formulation and in vitro evaluation of Metoprolol Succinate Floating Tablets by using two viscosity grade of HPMC. International Journal of Pharmaceutical Sciences and Research 2012; 3(9): 3507-13.

[10] Chandel A, Chauhan K, Parashar B, Kumar H and Arora S: Floating drug delivery systems: A better approach. International Current Pharmaceutical Journal 2012; 1(5): 110-18 